\title{
Protection of the Neostriatum against Excitotoxic Damage by Neurotrophin-Producing, Genetically Modified Neural Stem Cells
}

\author{
Alberto Martínez-Serrano and Anders Björklund \\ Wallenberg Neuroscience Center, Department of Physiology and Neuroscience, University of Lund, \\ Sölvegatan 17, S-223 62-Lund, Sweden
}

\begin{abstract}
Huntington's disease is a progressive neurodegenerative disease that affects the striatum, above all, the GABAergic striatal projection neurons. In the present study, we have explored the use of genetically modified neural stem cell lines producing nerve growth factor (NGF) or brain-derived neurotrophic factor (BDNF) as a means to protect the striatal neurons against excitotoxic damage after transplantation to the striatum, 1 week before the injection of quinolinic acid into the same area. One month after the lesion, striatal degeneration, lesion size, and loss of DARPP-32-positive projection neurons were only slightly affected by the BDNF-secreting cells, but substantially prevented when NGF-producing stem cells were used as a source of exogenous trophic factor; innervation of the target fields (pars reticulata of the substantia nigra and the globus pallidus) was preserved as well. Cholinergic striatal interneu-
\end{abstract}

rons (choline acetyltransferase-immunoreactive) were affected by the lesion and completely rescued by the NGF-transduced cells. The astroglial and microglial reactions to the excitotoxic lesion were substantially reduced in the striata, which had received transplants of NGF-producing cells. The generalized protective effects of the NGF-producing cell grafts in this model are discussed in the context of an indirect action preventing the development of toxicity mediated by cellular elements in the host striatum in response to the excitotoxin. We conclude that continuous supply of trophic factors by means of genetically modified neural stem cells represents a highly effective procedure to counteract neuronal degeneration in the excitotoxically lesioned striatum.

Key words: NGF; BDNF; gene therapy; medium-sized spiny projection neuron; quinolinic acid; striatum; excitotoxic injury
Huntington's disease (HD) is a progressive neurodegenerative disease that affects primarily the striatum. The loss of GABAergic medium spiny neurons, which is the most sensitive cell type, is accompanied by degeneration of the striatofugal inhibitory outputs to the pallidum and substantia nigra (Albin et al., 1989; Dunnett and Svendsen, 1993; Peschanski et al., 1995; Young, 1995). Neocortex and substantia nigra are probably affected as secondary events. In the striatum of HD patients, the cholinergic and the somatostatin/nicotinamide-adenine-dinucleotide phosphate-diaphorase (NOS) interneurons are relatively spared, at least during early stages of the disease (Dunnett and Svendsen, 1993; Young, 1995). Striatal neurodegeneration is accompanied by complex emotional, cognitive, and movement abnormalities that have been related to the progressive loss of striatal projection neurons (Albin et al., 1989).

The development of a possible therapy for HD based on effective procedures to preserve the integrity of the striatal complex, retaining the flow of information in the striato-pallidal-nigral circuit by blocking or retarding of the degeneration of the striatal projection neurons, remains a challenge for experimental and clinical research in HD. Experimental gene transfer procedures

\footnotetext{
Received Feb. 23, 1996; revised May 13, 1996; accepted May 16, 1996.

This work was supported by grants from the Human Frontier Science Program Organization, Åke Wiberg Foundation, Greta and Johan Kock Foundation, the Faculty of Medicine of the University of Lund, and the Swedish Medical Research Council Grants 19X-11632 (A.M.-S.) and 04X-3874 (A.B.). We thank Cristina Ciornei, Alicja Flasch, Kerstin Fogelström, Birgit Haraldsson, Ula Jarl, Sten Nilsson, AnnaKarin Olden, Agneta Persson, and Gertrude Stridsberg for their excellent technical assistance. The stereology work carried out in part by Soledad Conte is gratefully acknowledged.

Correspondence should be addressed to Alberto Martínez-Serrano at the above address.

Copyright (C) 1996 Society for Neuroscience $0270-6474 / 96 / 164604-13 \$ 05.00 / 0$
}

have provided a new approach to neuroprotection in the CNS based on the idea that supply of exogenous proteins to the brain could influence neurodegeneration and/or stimulate restorative processes in the affected brain region. Initially, ex vivo gene transfer to the brain was based on the use of fibroblastic tumorgenic cell lines or primary fibroblasts (for review, see Fisher and Ray, 1994). More recently, the generation of immortalized lines of CNS-derived neural stem cells has made it possible to obtain clonal, genetically homogeneous neural stem cell lines, which may allow refined ex vivo gene transfer to the CNS (for review, see Snyder, 1994; Gage et al., 1995; Martínez-Serrano and Björklund, 1996). These cells survive long-term, integrate into the surrounding host cytoarchitecture without any perturbation of the recipient brain, and are neither tumorgenic nor immunogenic. After genetic modification, neural progenitors engineered to release dihydroxyphenylalanine and dopamine have been shown to functionally compensate some of the deficits seen in an experimental model of hemiparkinsonism (Anton et al., 1994), and cells engineered to secrete trophic factors can provide the targeted regions with neurotrophic and neuroprotective support, accompanied by functional effects, such as the recovery from memory impairments in cognitively impaired aged rats (Martínez-Serrano et al., 1995a,b, 1996a,b). In a different context, genetically modified neural stem cells also have been used for gene transfer of metabolism-related enzymes, such as $\beta$-glucuronidase (Snyder et al., 1995) or $\alpha$-hexosaminidase (Lacorazza et al., 1996).

In the present report, we have investigated whether two of these neural stem cell lines, transgenically producing NGF or BDNF, may counteract the main cellular deficit observed in HD, i.e., the loss of striatal GABAergic medium spiny projection neurons and the concomitant degeneration of the striatum, in a rat HD model 
based on the excitotoxic lesion of the striatum with quinolinic acid (for review, see DiFiglia, 1990; Dunnett and Svendsen, 1993; Björklund et al., 1994).

\section{MATERIALS AND METHODS}

Ex vivo gene transfer. The cells used in this study were derived from a conditionally immortalized neural stem cell line generated from the embryonic hippocampus, the HiB5 cell line (Renfranz et al., 1991). By retrovirally mediated genetic transduction followed by subcloning, two cell lines secreting recombinant mouse NGF or human BDNF (clones E8 and $\mathrm{C}$, respectively) were isolated and characterized in vitro and in vivo; secretion rates were estimated to be $2 \mathrm{ng} \mathrm{NGF}$ or $0.28 \mathrm{ng} \mathrm{BDNF} / \mathrm{hr} / 10^{5}$ cells (Martínez-Serrano et al., 1995a, 1996a). A negative clone (named D11) obtained during the isolation of the NGF-secreting cells that does not produce either NGF or BDNF was used in a control-grafted animal group.

These cell lines were all cultured at $33^{\circ} \mathrm{C}$ in Dulbecco's modified Eagle's medium supplemented with $10 \%$ fetal bovine serum, 10,000 units/ml penicillin/streptomycin, and $2 \mathrm{~mm}$ glutamine. The cells were labeled in culture for $72 \mathrm{hr}$ before grafting in the presence of $1 \mu \mathrm{Ci} / \mathrm{ml}$ of $\left[{ }^{3} \mathrm{H}\right]$ thymidine (Amersham). For transplantation, the cultures were trypsinized, stored at $4^{\circ} \mathrm{C}$ in suspension at a cell density of $1.5 \times 10^{5}$ cells $/ \mu \mathrm{l}$, and used within $3 \mathrm{hr}$ after trypsinization.

Animal groups and surgery. The animals used in this study $(n=28$, weighing $225 \mathrm{gm}$ at the beginning of the experiment) were female Sprague-Dawley rats (B\&K Universal, Stockholm, Sweden) housed and treated following institutional guidelines and divided into four groups: sham-grafted $(n=4)$, control-grafted $(n=8)$, NGF-grafted $(n=8)$, and BDNF-grafted $(n=8)$. All animals underwent transplantation surgery 1 week before receiving a quinolinic acid lesion. The animals were transplanted at three different sites in the right striatum at the following coordinates [tooth bar $(\mathrm{TB})=-2.3$ ]: AP (anteroposterior from bregma) $=+1.7, \mathrm{ML}$ (mediolateral $)=-2.1, \mathrm{~V}$ (vertical from dura $)=-5.0$ and $-4.0 ; \mathrm{AP}=+1.2, \mathrm{ML}=-3.1, \mathrm{~V}=-5.0$ and $-4.0 ; \mathrm{AP}=+0.7, \mathrm{ML}=$ $-2.1, \mathrm{~V}=-5.0$ and -4.0 . The cells were injected in two $1 \mu \mathrm{l}$ deposits at each injection site, each animal receiving a total of 900,000 cells (in a total volume of $6 \mu \mathrm{l})$. Sham-grafted animals received the same volume $(6 \mu \mathrm{l})$ of the buffer used to prepare the cell suspensions (Hank's balanced salt solution, Life Technologies). One week after cell implantation, all animals received a quinolinic acid injection (225 nmol in $2 \mu$ l, Sigma) into the same striatal region $(\mathrm{TB}=-2.3, \mathrm{AP}=+1.2, \mathrm{ML}=-2.6, \mathrm{~V}=-4.5)$. The left hemisphere did not receive any surgery and served as histological control and to evaluate lesion and treatment effects. By the end of the experiment, all groups had similar body weight, indicating no adverse effects of the treatments (sham graft $=295 \pm 6 \mathrm{gm}$; control graft $=280 \pm$ $10 \mathrm{gm} ; \mathrm{NGF}$ graft $=301 \pm 7 \mathrm{gm} ; \mathrm{BDNF}$ graft $=313 \pm 16 \mathrm{gm})$.

An additional group of 18 animals received grafts of the D11, E8, or C7 cells (negative control, NGF-, or BDNF-producing cells, respectively) under the same conditions (coordinates, cell numbers, and survival time) as above, except that they did not receive any lesion. These animals were used to compare the survival characteristics of the grafted cells with and without a quinolinic acid lesion (see Results section).

Histology. One month after the lesion, the rats were killed under chloral hydrate anesthesia and transcardially perfused with $250 \mathrm{ml}$ of chilled buffered $4 \%$ paraformaldehyde. The brains were post-fixed overnight in the same solution and equilibrated in $30 \%$ sucrose for $24 \mathrm{hr}$. Series of sections $(40 \mu \mathrm{m}$ thick) were taken in the coronal plane and stained for Nissl substance or immunostained for DARPP-32 (1:20,000; a gift from Dr. P. Greengard, Rockefeller University, New York, NY), choline acetyltransferase (ChAT) (1:1000; Chemicon, hybridoma 1E6), glial fibrillary acidic protein (GFAP; 1:50; rabbit polyclonal, DAKO), and OX-42 (monoclonal MRC OX-42; Serotec, Oxford, UK, used at 1:100). Immunohistochemistry was performed following published procedures (Isacson et al., 1987; Wictorin et al., 1989; Duan et al., 1993; MartínezSerrano et al., 1996a). For $\left[{ }^{3} \mathrm{H}\right]$ thymidine autoradiography, one series of mounted sections was dipped in K5 ILFORD photographic emulsion, exposed for 4 weeks, developed, and lightly counterstained with cresyl violet.

Morphometric analyses. The morphometric analyses were done according to established stereological procedures (Gundersen et al., 1988) using the GRID software (Intractivision, Glostrup, Denmark) to avoid biased field sampling of the histological sections. First, we determined the rostrocaudal level in which the lesion was maximal in DARPP-32 immunostained sections after determining the profiles of the striatal lesion and the area of the contralateral (intact) and ipsilateral (lesion + graft) striatum. Area measurements from every section in the DARPP-32stained section series (every 10th section through the entire caudateputamen) were integrated to obtain absolute striatal volume figures. After this level was determined, three sections at that level were chosen to quantify surviving DARPP-32 and ChAT-positive neurons; using the GRID software, the entire cross section of the caudate-putamen of both hemispheres was analyzed in each animal by randomly selecting fields in which neuron counts were quantified. Total neuronal cell counts and densities were then computed and expressed either as absolute cell numbers or percentage of the intact side. In the ChAT-immunostained sections, the intensity of the staining of cholinergic interneurons (and hence cell counts) on the intact side varied between animals; for this reason, total neuronal numbers were not calculated, and the results are presented as numbers of ChAT-positive cells counted on the lesioned side relative to the contralateral intact side.

Optical density determinations. The innervation of the substantia nigra (pars reticulata) and globus pallidus by DARPP-32 immunostained striatal fibers was analyzed using the National Institutes of Health Image software (Wayne Rasband, National Institute of Mental Health) on a Macintosh Centris 650 computer connected to an MTI-72 CCD video camera and a constant illumination light table. The area of the DARPP32-stained regions and the optical density were quantified from frozen images, with all the components of the system set to ensure that quantifications were done in the dynamic range of the camera. At every rostrocaudal level, the analyzed regions were defined based on published anatomical landmarks (Paxinos and Watson, 1986). In every case, the intact hemisphere served as reference to express the results as the ratio of stained area or optical density of the lesioned + graft side relative to the nonlesioned hemisphere. Every 10th section from the series that cut through the globus pallidus or substantia nigra, spanning the whole structure, was analyzed. The result for each animal is the average of the individual figures obtained for each level.

Statistical analyses. Comparisons between groups were done by oneand two-way ANOVA followed by Fisher protected least significant difference post hoc analyses at a significance level of 95\% using Statview software. Results are presented as groups mean \pm SEM.

\section{RESULTS \\ Engraftment of neural stem cell lines producing NGF}

One week before the quinolinic acid lesion, the rats received transplants of control, NGF-, or BDNF-producing neural stem cells, or received buffer injection (sham surgery) into the striatum on one side. The cell lines used in this study have been characterized elsewhere (Martínez-Serrano et al., 1995a,b, 1996a,b). A total of 900,000 cells were distributed over three sites so that the placements surrounded the region to be lesioned 1 week later. These neural stem cells are able to migrate from the implantation site and integrate into the surrounding host tissue so that within 1 week after transplantation, the grafted cells will be distributed over a large area of the head of the caudate-putamen (Fig. 1) (for details, see Martínez-Serrano et al., 1995a). This feature, common to the control and neurotrophin-producing cell lines, should allow for a widespread and evenly distributed biological supply of the transgenic neurotrophic factors within the striatum.

At the time of killing, 1 month postlesion and 5 weeks postgrafting, all animals had surviving grafts as assessed by $\left[{ }^{3} \mathrm{H}\right]$ thymidine autoradiography. Consistent with previous studies characterizing these or the parental cell lines (Martínez-Serrano et al., 1995a,b, 1996a,b), the ${ }^{3} \mathrm{H}$-thymidine-labeled cells were distributed through the head of the caudate-putamen (Fig. 1A,B), and the majority of the grafted cells had a glial-like morphology, as judged by the size and shape of the cells in Nissl-stained sections (Fig. $1 C$ ). Thus, the endogenous production of different (transgenic) factors did not seem to alter the survival properties of the grafted cells. Three separate control groups of animals ( $n=6$ per group) were transplanted at the same coordinates with equal numbers of 

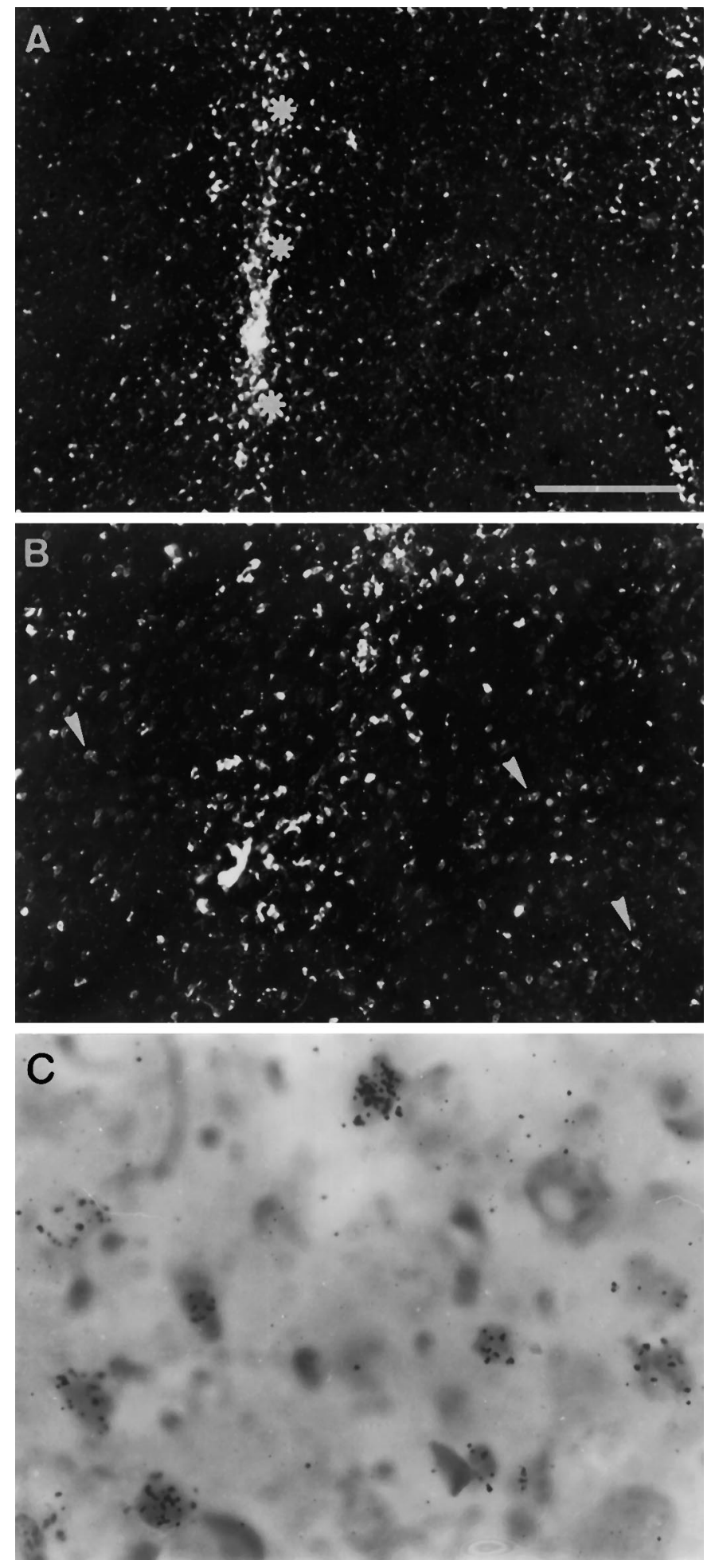

Figure 1. Engraftment of the immortalized neural stem cells in the striatum. Dark-field photomicrographs of autoradiograms of the ${ }^{3} \mathrm{H}$ thymidine-labeled grafted neural stem cells $(A, B) 1$ month after transplantation in the striatum. Individual cells are recognized as clusters of silver grains in the autoradiograms (arrowheads). Note the anatomical integration of the cells into the host brain tissue around the initial implantation site (asterisks in $A$ ). $B$ is a higher magnification of the lowest portion of the graft shown in $A$. $C$, Bright-field image of the Nissl-stained grafted NGF-secreting cells illustrating the small size and dark staining shown by the grafted cells, identified by silver grains in the emulsion, reminiscent of glia. Scale bar (shown in $A$ ), $200 \mu \mathrm{m}$ in $A, 100 \mu \mathrm{m}$ in $B$, and $50 \mu \mathrm{m}$ in $C$. cells, but did not receive any lesion. Comparison of the lesioned and nonlesioned grafted striata did not reveal any remarkable difference in the appearance of the grafted cells, suggesting no sensitivity of the cell lines to the excitotoxic lesion (not shown).

\section{Protection from excitotoxic damage}

One month after the excitotoxic lesion (5 weeks after transplantation), the brains were histologically analyzed to evaluate the degree of damage to the caudate-putamen. Nissl-stained sections revealed major neuronal cell loss after quinolinic acid injection in the sham-operated or control-grafted animals; the lesion induced almost complete depletion of neurons in a region spanning $\sim 2$ $\mathrm{mm}$ in both the rostrocaudal and the mediolateral direction through the head of the caudate-putamen. In contrast, in the NGF cell-transplanted rats and, to a lesser extent, in the rats that had received BDNF-secreting cell grafts, morphologically normal neuronal cell bodies could be identified close and distant to the toxin injection site. The quinolinic acid lesions were accompanied by striatal atrophy and tissue loss, as evidenced from the enlargement of the lateral ventricle ipsilateral to the lesion; tissue sparing was evident in the animals receiving NGF-secreting grafts compared with the other groups (as illustrated in Fig. 3).

The spiny projection neurons in the striatum can be unequivocally identified by the expression of the neuronal phosphoprotein DARPP-32 (dopamine- and adenosine-3',5'-monophosphateregulated phosphoprotein). This marker of dopamine-sensitive neurons (Ouimet et al., 1984) is expressed both in the cell bodies and along their axonal projections innervating the globus pallidus and substantia nigra. The DARPP-32-immunostained sections revealed those regions most affected by the lesion, identified by the loss of immunostaining; representative photomicrographs of the lesioned area (macroscopically devoid of DARPP-32 staining) are illustrated in Figure 2. The quinolinic acid dose used here induced, 1 month after lesion, a near-to-complete depletion of DARPP-32 staining in a large part of the head of the caudateputamen (rostral to the anterior commissure, preferentially in the dorsal half). In the sham- and control-grafted rats, the lesion reached its maximal extent at a rostrocaudal level $1.3 \mathrm{~mm}$ anterior to bregma and affected $>50 \%$ of the entire cross sectional area of the striatum at this level. The morphometric analysis of the DARPP-32-depleted lesioned area at different anteroposterior levels is given in Figure $3 A$. The extension of the area devoid of DARPP-32 staining in the NGF-transplanted group was significantly smaller than in the sham- or control-grafted animals (Fig. $3 A$ ), particularly at the levels at which the lesion was maximal (0.5-1.5 mm anterior to bregma). Quantification of the absolute volume of the lesion (from areas devoid of DARPP-32 staining) revealed a $60 \%$ reduction of the size of the lesioned region in the NGF group $\left(3.33 \pm 0.9 \mathrm{~mm}^{3}\right)$ compared with the sham and control graft group $\left(8.21 \pm 1.52 \mathrm{~mm}^{3}\right)$ (Fig. $\left.3 B\right)$. BDNF-grafted animals showed an intermediate degree of protection (lesion volume $=5.91 \pm 0.86 \mathrm{~mm}^{3}$ ).

At the time point investigated in this study, 1 month after the quinolinic acid lesion, the striatum as a whole has already started to degenerate, which results in a significant shrinkage of the structure and, as mentioned above, the enlargement of the lateral ventricle in the hemisphere receiving the lesion (Fig. 2). Measurements of the absolute volume of the striatum revealed a reduction of $>15 \%$ in volume in the sham- and control-grafted animals compared with the intact striatum (total volume of the structure was calculated by integrating the area in serial sections over the entire rostrocaudal extension of the caudate-putamen; i.e., from 

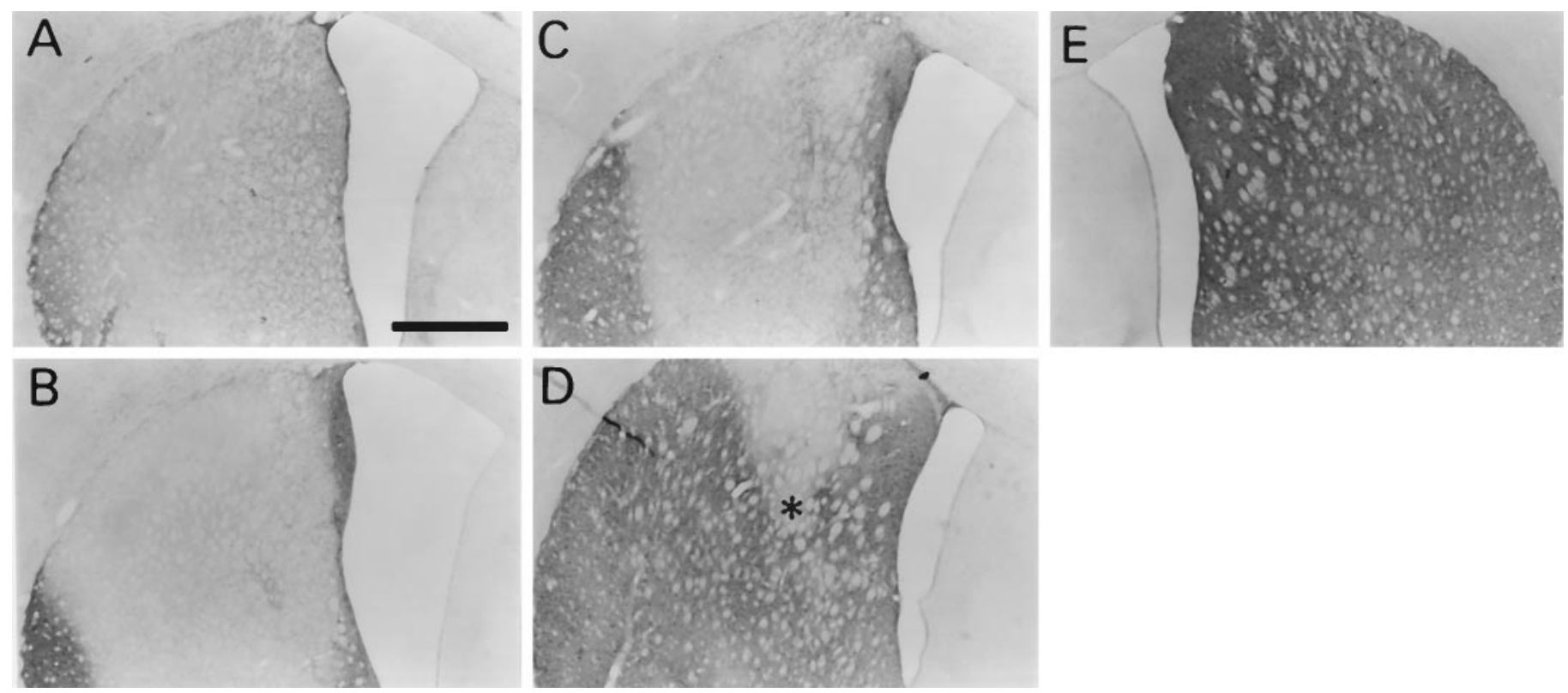

Figure 2. Lesion and neurotrophin gene transfer effects on the DARPP-32-immunoreactive neuronal striatal population. The photomicrographs show low-power magnifications of the head of the caudate-putamen in sections immunostained for DARPP-32 in animals belonging to the sham $(A)$ and control $(B)$ graft group or in rats receiving BDNF- $(C)$ or NGF- $(D)$ secreting transplants 1 week before quinolinic acid injection at the end of the experiment ( 1 month after the excitotoxic lesion). As a consequence of the lesion and concomitant tissue loss in the lesioned striatum, there is an apparent enlargement of the lateral ventricle, which is reduced in the NGF-grafted group $(D)$. The nonlesioned, intact side is shown in $E$ for histological reference. Scale bar, $1 \mathrm{~mm}$. The results of the morphometric analyses of this material are presented in Figures 3 and 6 . The asterisk in $D$ marks the area shown at larger magnification in Figure 4.

-2.5 to $+2.5 \mathrm{~mm}$ relative to bregma). BDNF cell-grafted rats showed only a slight decrease in the degree of atrophy, but in the rats receiving NGF-secreting transplants, the tissue loss was reduced by $\sim 30 \%$ (Fig. 3C).

The determination of lesion volume (Fig. $3 B$ ) was performed in a structure that has shrunk to a different degree between groups receiving different treatments. For this reason, the percentage of striatal volume affected by the lesion was calculated to define more accurately the degree of protection. The results, plotted in Figure $3 D$, revealed a significant $60 \%$ reduction in the portion of the striatum that was affected by the lesion in the NGFtransplanted animals $(11.55 \pm 3.91 \%)$ compared with the shamand control-grafted group $(26.58 \pm 4.25 \%)$.

\section{Protection of the population of medium-sized spiny striatal projection neurons}

Analysis at the cellular level of the DARPP-32-immunostained sections revealed major differences in the sensitivity of the striatal projection neurons to the lesion in the different treatment groups, indicative of a protective effect of the trophic factor producing cell grafts. Within the macroscopically defined lesioned area, DARPP-32-immunoreactive neuronal profiles were virtually absent in the sham and control groups (Fig. $4 B$, compared with the intact tissue in Fig. 4A). This neuronal population was substantially preserved in the animals receiving NGF cell grafts (Fig. 4D); again, the BDNF-grafted group showed an intermediate degree of rescue (Fig. $4 C$ ). Stereological quantification of the total number of DARPP-32-positive neurons, measured throughout the cross section of the caudate-putamen in three sections from the rostrocaudal levels where the lesion was maximal (spanning $920 \mu \mathrm{m}$ in the anteroposterior axis, centered at $+1.3 \mathrm{~mm}$ relative to bregma), confirmed this observation (see Fig. $6 \mathrm{~A}$ ). Whereas only $32 \%$ of the DARPP-32-positive neurons remained in the sham- and control-grafted striata, the number of DARPP-32-positive neurons approached $75 \%$ of those in the intact side in the NGF cell-grafted group. Thus, nearly two-thirds of the neurons in the injured striatum that normally die after the quinolinic acid injection in the absence of any trophic support were rescued by the NGF-releasing grafts, whereas in the BDNF group, less than one-third were rescued ( $48 \%$ of intact side, Fig. $6 A$ ). Similar results were obtained when the data were expressed as total cell numbers (Fig. 6 A, left) or as cell density (number of cells per unit area, Fig. $6 A$, right).

\section{Protection of striatal cholinergic interneurons}

To be able to compare the results of the present study to other reports, we analyzed the sensitivity of the cholinergic striatal interneurons (ChAT-positive immunoreactive profiles) to the lesion and rescue effects of the different cell grafts. Similar quantifications of neuronal numbers to the ones presented above for DARPP-32-positive projection neurons were done for the cholinergic population. The immunostaining in some representative animals at the level of the maximal extent of the lesion (see Fig. 3 ) is illustrated in Figure 5. The quinolinic acid injection caused a profound depletion of ChAT-immunoreactive neurons, except in the group receiving NGF-secreting grafted cells. NGF-secreting grafts clearly rescued all ChAT-positive neurons: indeed, there was a relative increase compared with the intact hemisphere in cell counts of neurons identified as ChAT-immunoreactive (intact side $=100 \%$; lesioned striata: sham and control graft $=49 \pm 8 \%$, BDNF graft $=63 \pm 12 \%$, NGF graft $=116 \pm 11 \%, p<0.05$, NGF graft vs any other group). The same results were obtained when comparing either actual cell counts or cell densities between groups (Fig. 6B, left and right panels). 

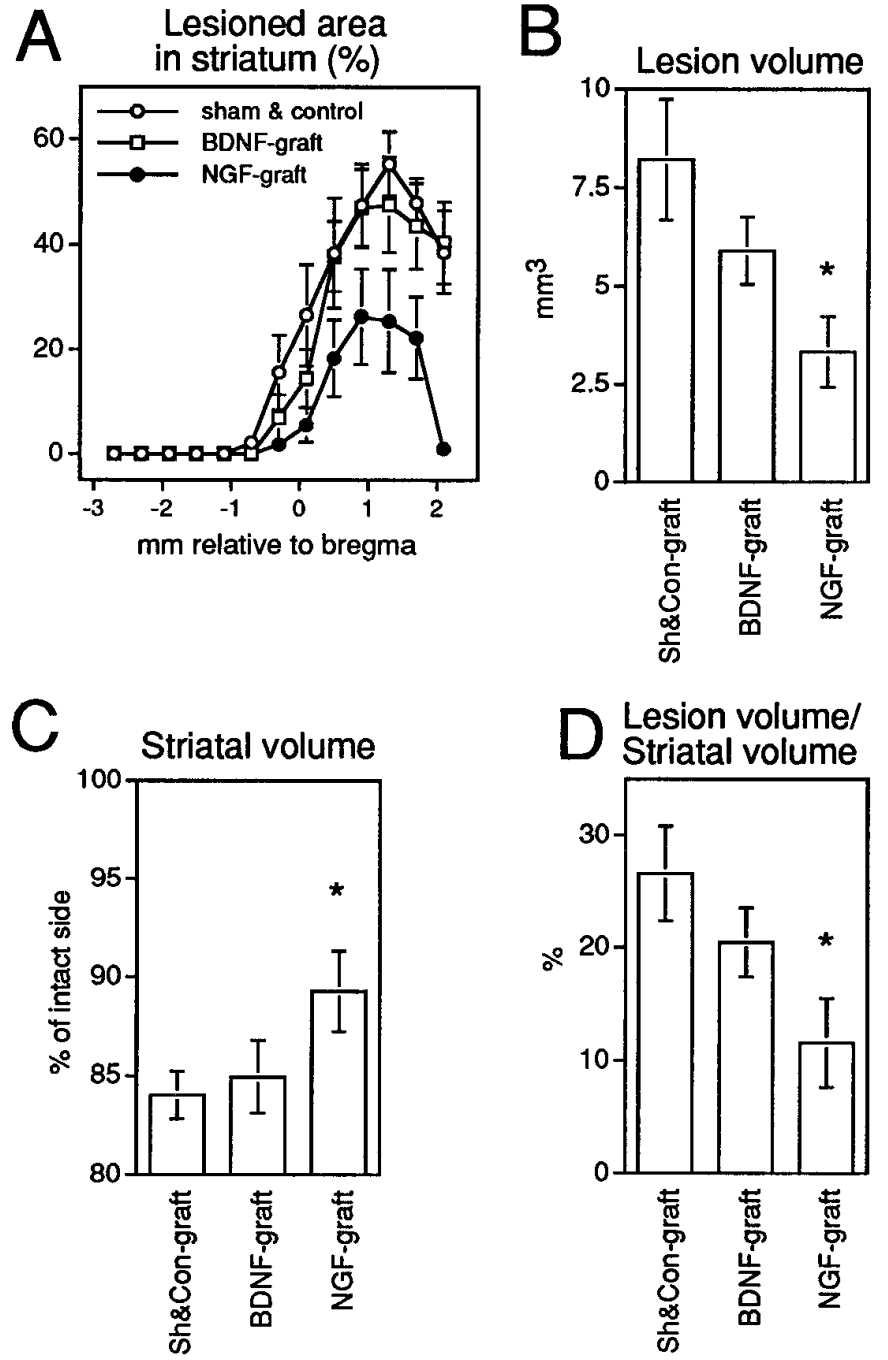

Figure 3. Morphometric analyses of striatal and lesion volumes based on DARPP-32 striatal immunostainings along the whole extent of the caudate-putamen. $A$, Rostrocaudal distribution of lesion sizes in the different treatment groups expressed as percentage of the area of the striatum in the lesioned-and-grafted side (lesioned area is defined as the tissue devoid of DARPP-32 staining). $B$, Absolute lesion volume, calculated after integration of the area of the lesion from every section in the lesioned-and-grafted striatum. $C$, Relative striatal volume expressed as the percentage of the volume of the striatum in the lesioned side to the intact side and calculated for the complete rostrocaudal extent of the nucleus (every 10th section from -2.5 to +2.5 relative to bregma). $D$, Relative volume of the lesioned region expressed as percentage of the striatum volume in the same hemisphere (normalized lesion size). In all cases, the sham-operated and control-grafted groups were combined because they did not show any significant difference, as can be appreciated in Figures 2 and $3 .{ }^{*} p<0.05$, NGF-grafted versus sham and control-grafted group.

\section{Integrity of the striato-pallidal-nigral pathway}

Different subpopulations of the medium-sized spiny striatal projection neurons innervate the globus pallidus and the substantia nigra. Given the protective effects of the NGF-secreting cell grafts on the integrity of these neurons after injection of quinolinic acid in the striatum, we examined whether this protection was reflected in a preservation of the striatofugal output projection pathways by analyzing the extent of innervation of the two target fields by
Table 1. Innervation of the pars reticulata of the substantia nigra and the globus pallidus region by DARPP-32-immunoreactive fibers

\begin{tabular}{lcll} 
& Area $^{a}$ & Optical density $^{a}$ & $\begin{array}{l}\text { Area } \times \\
\text { optical density }^{a}\end{array}$ \\
\hline $\begin{array}{l}\text { Substantia nigra } \\
\text { Sham and control }\end{array}$ & $74.2 \pm 2.3$ & $72.4 \pm 3.6$ & $60.2 \pm 4.8$ \\
BDNF & $79.2 \pm 8.4$ & $80.4 \pm 5.4$ & $66.9 \pm 10.8$ \\
NGF & $92 \pm 1.4^{*}$ & $85.6 \pm 4.2$ & $80.1 \pm 4.8^{*}$ \\
Globus pallidus & & & nd \\
Sham and control & nd & $54.6 \pm 4.7$ & nd \\
BDNF & nd & $81.6 \pm 6.3^{*}$ & nd \\
NGF & nd & $89.7 \pm 5^{*}$ &
\end{tabular}

*, $p<0.05$ from sham and control-grafted group. nd, Not determined.

${ }^{a}$ Values are expressed as percentage of intact side.

DARPP-32-immunoreactive fibers. As shown in Figure 7, the innervation of the substantia nigra pars reticulata $(\mathrm{SNr})$ appeared as close to normal in the NGF cell-transplanted animals (Fig. 7D; the intact side staining pattern is shown for comparison in $A$ ), whereas the sham- and control- or BDNF cell-grafted animals showed a marked reduction in the DARPP-32-positive innervation. For the semiquantification of the intensity of the immunostaining, optical density and area measurements were taken from the intact and lesioned and grafted side in the same sections. As shown in Table 1, both the area of DARPP-32-positive innervation and the intensity of the immunostaining (optical density) were reduced by $\sim 20-30 \%$ in the sham and control and the BDNF groups. The parameter that most closely reflects the degree of innervation is the integrated optical density (area $\times$ optical density); on this measure, the NGF-secreting cell grafts significantly reduced the loss of innervation by half, i.e., from 60 to $80 \%$ of normal $(p<0.05)$, which is consistent with the cell loss and rescue effects observed for the striatal DARPP-32 neuronal population in the striatum (Fig. $6 A$ ).

In the globus pallidus, the sham- and control-grafted animals exhibited a substantial reduction in DARPP-32-positive innervation, which was significantly counteracted by the NGF cell grafts and, to a lesser extent, also by the BDNF-producing cells (Fig. 8). Averaged optical density readings, obtained throughout the extension of the structure in the coronal sections, showed that the density of innervation was reduced by 10 and $20 \%$ in the NGF or BDNF cell-grafted animals, respectively, as opposed to the $45 \%$ reduction seen in the sham- and control-grafted group (Table 1) $(p<0.05$, for both the NGF and BDNF groups vs sham and control).

Thus, these results demonstrate that the protection of the DARPP-32-positive neurons in the striatum is indeed reflected in a preserved innervation of the two major target fields, thus retaining the anatomical substrates for information flow between the major components of the striato-pallidal-nigral circuit.

\section{Reduction of astroglial and microglial reaction to the excitotoxic lesion}

Glial reaction to neuron injury is a prominent feature in the course of HD, which parallels the loss of the striatal projection neurons (DiFiglia, 1990); reactions also occur after excitotoxic lesion in the CNS (Isacson et al., 1987; Dusart et al., 1991; Marty et al., 1991). Consistent with these reports, there was a massive upregulation of $\mathrm{GFAP}^{+}$reactive astrocytes and reactive micro- 

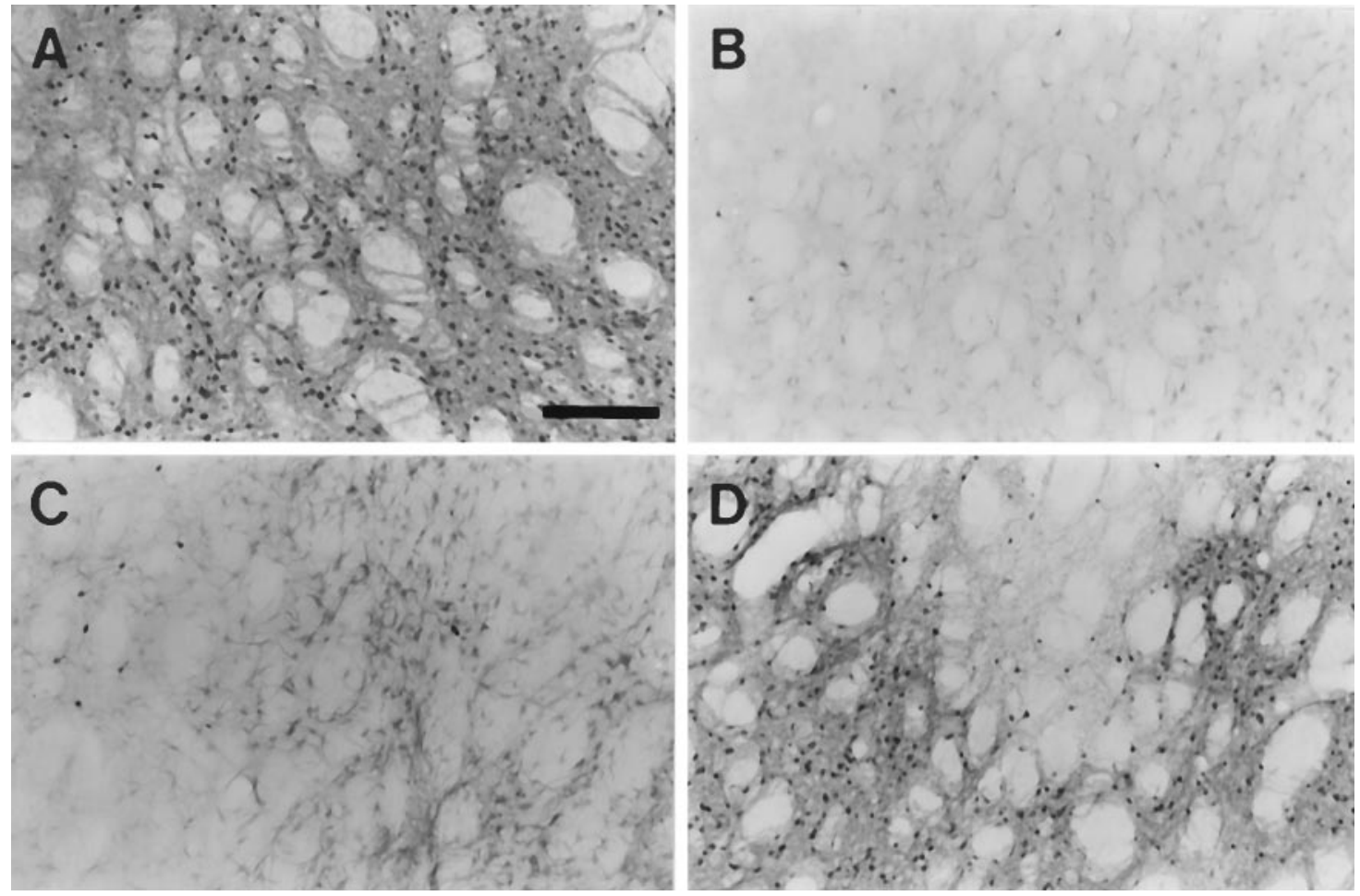

Figure 4. Rescue of the DARPP-32-immunoreactive striatal projection neurons by neurotrophin gene transfer. The photomicrographs show neuronal cell bodies in the head of the caudate-putamen (same levels and specimens as in Fig. 3, photographs taken at the region denoted with an asterisk in Fig. $3 D)$ in the intact side $(A)$ or in the control- $(B)$, BDNF- $(C)$, and NGF- $(D)$ transplanted striata. Scale bar, $200 \mu \mathrm{m}$.

glia, occupying most of the lesioned area in the control, nonprotected groups (Fig. 9B,F). Both the astrocytic and the microglia reactions were substantially reduced in the NGF-grafted animals, which was in contrast to the large areas showing high density of GFAP- or OX-42-immunoreactive profiles in all other groups (compare in Fig. $9 D$ with $B$ and $C$, and $H$ with $F$ and $G$ : GFAP and OX-42 immunostainings, respectively). This marked reduction in glial reactions at the lesion site in the animals grafted with NGF-secreting cells parallels the decrease in lesion size and neuronal degeneration described above.

\section{DISCUSSION}

\section{Efficiency of neural stem cell-mediated trophic factor supply}

The procedure used in the present report, based on the transplantation of modified neural stem cell lines, overcomes the problems related to tumor formation by the grafted cells and ensures an even supply of the trophic factors over a large area of the striatum (attributable to the moderate migration of the cells into the surrounding host tissue), which is in contrast to the point-source delivery obtained with compact fibroblast grafts and capsules. The use of neural stem cells for gene transfer thus allows the study of effects of neurotrophin delivery also on the late degenerative phenomena that follow the initial excitotoxic cell death. These more slowly evolving processes, which include progressive slow cell death, striatal atrophy and gliosis, as well as secondary changes in striatal target structures, are thought to more closely resemble the neurodegenerative changes seen in human HD (Tatter et al., 1995; Young, 1995). Indeed, both the acute neuronal degeneration and the more slowly developing degenerative changes, such as striatal atrophy and gliosis, were efficiently counteracted by the NGF-secreting neural stem cells over the 1 month postlesion observation period used here.

Schumacher et al. (1991) and Frim et al. (1993a,b), using trophic factor-secreting engineered tumorgenic fibroblastic cell lines, were the first to report protective effects of NGF-secreting cells against the toxic effects of intrastriatal quinolinic acid. This procedure did not produce as complete protection as the transduced stem cells used here, and the tumorgenic characteristics of the fibroblastic cell lines precluded any experimental observations beyond the acute phase of the lesion, i.e., 1-2 weeks posttransplantation. Thus, in the study of Schumacher et al. (1991), grafts of NGF fibroblasts rescued less than half of the striatal neurons (as assessed in cresyl violet-stained sections) after a quinolinic acid lesion (Schumacher et al., 1991); the more recent experiments by Frim et al. (1993b), using the same cellular vector but with the grafts placed over the corpus callosum, reported an even lower efficiency in the reduction of lesion volume after injection of quinolinic acid (20\% reduction at $10 \mathrm{~d}$ postlesion, using half the dose of quinolinate used in the present report). These data suggest that NGF expression by cells that are evenly dispersed over the lesion area, such as the stem cells used here, may provide more effective neuroprotection than fibroblast cells, which form a circumscribed cellular aggregate.

Polymer capsules containing NGF-secreting baby hamster kidney fibroblasts have also been reported to be effective in this model (Emerich et al., 1994); however, no quantitative assessment of the magnitude of neuronal rescue was reported in this work. It is noteworthy to mention at this point that differences in the procedures used to assess neuronal rescue and changes in lesion 


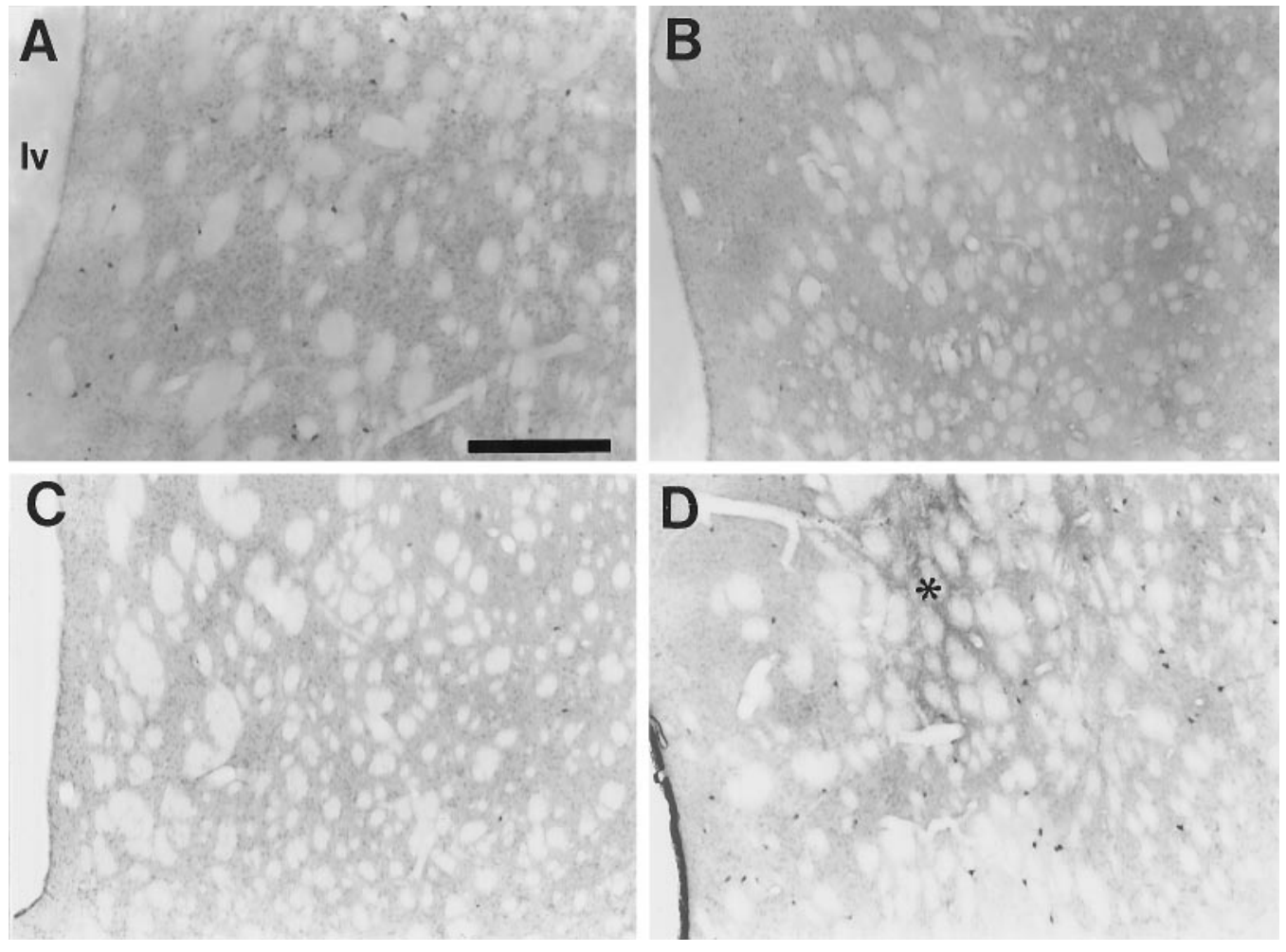

Figure 5. Cholinergic interneuron (ChAT-immunoreactive neuronal profiles) cell number is decreased by the excitotoxic lesion and rescued by NGF. The photomicrographs represent fields from adjacent sections to those shown in Figures 3 and 5, immunostained for ChAT to illustrate the near-to-complete depletion of neurons in the nonprotected animals, sham- or control-grafted $(B)$ or BDNF-grafted $(C)$ groups, whereas most of them are present in the NGF- $(D)$ grafted animals. Scale bar, $500 \mu \mathrm{m}$. $l v$, Lateral ventricle.

size, as well as variations in details of the lesion procedure, preclude any direct comparison between different reports, as discussed by Roberts et al. (1993) and Dunnett and Svendsen (1993). For this reason, we chose to quantify not only cell numbers at the most severely lesioned region, but also obtain morphometric data from the whole rostrocaudal extent of the striatum as a way to understand the relevance of the lesion in the context of the complete structure. As shown in Figure 3, the quinolinic acid lesion used here affected $\sim 25 \%$ of the entire striatum, whereas quantification of the region where lesion was maximal (i.e., the head of the caudate-putamen) showed that $\sim 60 \%$ of the structure was severely damaged at this level; moreover, as illustrated in Figure 2, the neuronal depletion in the dorsal half of the head of the caudate-putamen reached a much higher value, close to $100 \%$.

\section{Protection of cholinergic striatal interneurons}

The cholinergic population of striatal interneurons was protected from the toxic effects of quinolinic acid injection when the striatum was supplied with NGF-producing stem cells 1 week before the lesion, which is consistent with previous reports using infusion or injection of exogenous NGF (Davies and Beardsall, 1992; Venero et al., 1994a), systemic NGF delivery (Kordower et al., 1994), or NGF-secreting fibroblastic cell lines (Frim et al., 1993a; Emerich et al., 1994). In the present study, NGF gene transfer resulted in an even larger number of ChAT-immunoreactive detectable neurons in the lesioned and grafted striatum compared with the contralateral intact striatum. This probably reflects not only rescue of the complete set of cholinergic neurons, but also upregulation of the cholinergic enzyme in otherwise low ChAT- expressing cells as a consequence of an increased supply of NGF to these neurons, in agreement with previous reports using injections or infusions of purified NGF (Hagg et al., 1989; Venero et al., 1994a). The extent of protection seen with the NGF-producing stem cells is similar to that obtained with infusions of purified NGF at a dose of $1 \mu \mathrm{g} / \mathrm{d}$, assessed at the cellular level by means of ChAT in situ hybridization (Venero et al., 1994a) or acetylcholinesterase histochemistry (Davies and Beardsall, 1992). The rescue of cholinergic neurons in the present lesion model can be viewed as an internal control to demonstrate that the grafted NGF cells produced NGF at a physiologically effective level (cf. Martínez-Serrano et al., 1995a,b, 1996b). It should be pointed out, however, that cholinergic neuronal rescue in itself may have important functional implications, because striatal cholinergic interneurons provide excitatory regulatory input both onto other interneurons and the GABAergic projection neurons, thereby controlling the excitability of the ouput neurons of the striatum (Chang and Kita, 1992; Björklund et al., 1994; DiChiara et al., 1994; Kawaguchi et al., 1995; Parent and Hazrati, 1995).

\section{Protection of striatal projection neurons}

As recently discussed by Tatter et al. (1995), the in vivo mechanism by which NGF exerts its trophic effects on striatal medium spiny projection neurons remains obscure. Classic NGF receptors (p75 ${ }^{\text {NTR }}$ or Trk) are absent in these neurons under normal conditions in vivo (Holtzman et al., 1992; Merlio et al., 1992), and they are upregulated in response to increased levels of NGF only in striatal cholinergic interneurons, but not in other neurons or glia (Gage et al., 1989; Higgins et al., 1989; Holtzman et al., 1992; 

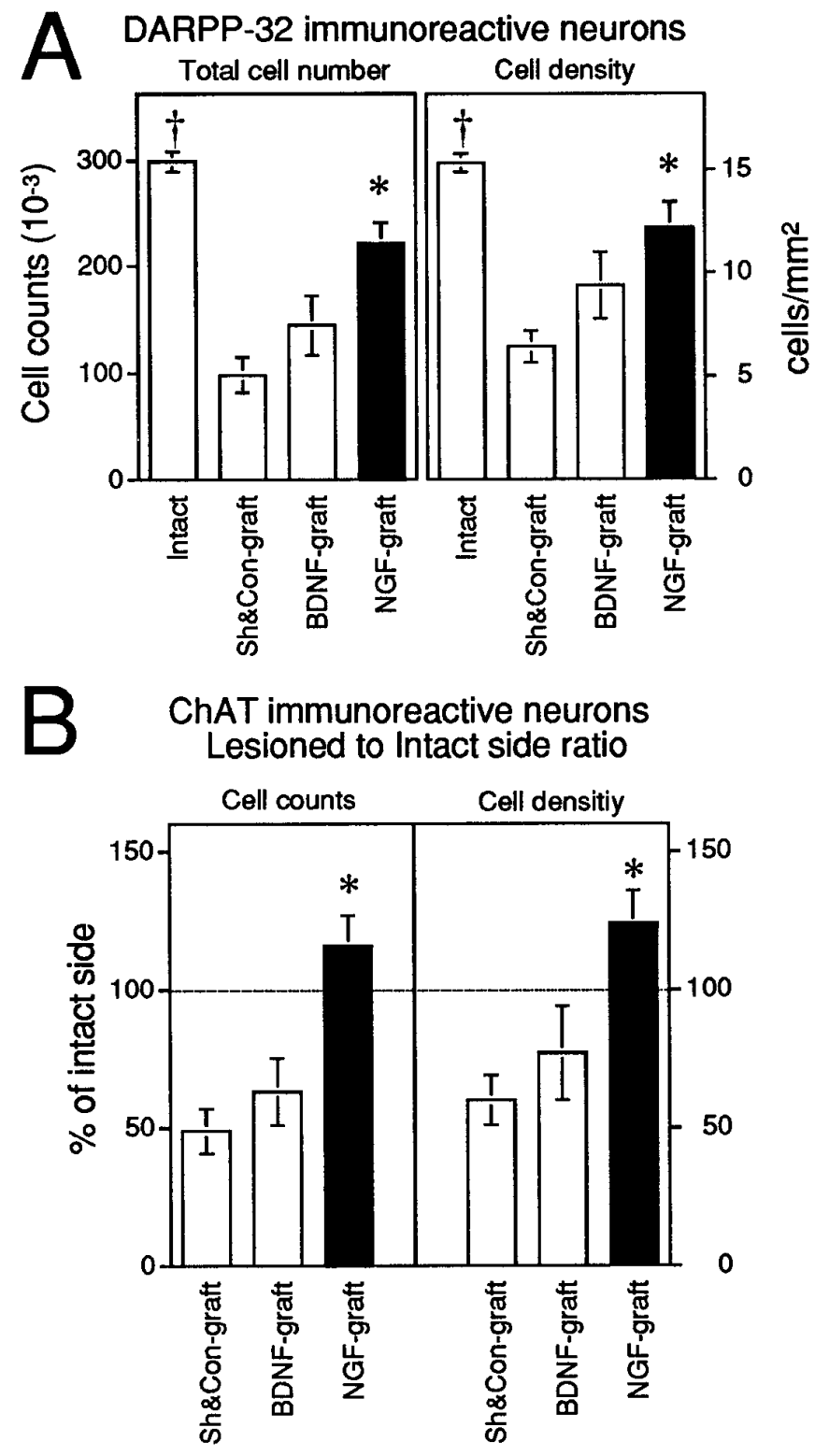

Figure 6. Cell morphometric analyses of neuronal rescue (DARPP-32, GABAergic projection neurons, and ChAT-positive cholinergic interneurons) by neurotrophin gene transfer. For DARPP-32 neurons $(A)$, total cell counts and cell densities are shown, integrated from three levels at the head of the caudate-putamen (as detailed in Materials and Methods), whereas for the cholinergic interneurons $(B)$, figures are given as percentage of the intact side for those same three levels. Sham and control-grafted groups are combined in a single group because there is no statistical difference among them. In the "cell counts" plot in $A, \dagger$ indicates different from the rest of the groups, and * indicates different from sham and control- and BDNF-grafted groups; in the "cell densities" graph in $A, \dagger$ indicates different from the sham and control- and BDNF-grafted groups, and ${ }^{*}$ indicates different from sham and control-grafted group; in $B$, * indicates different from the BDNF- and sham and control-grafted groups. In all cases, $p<0.05$.

Venero et al., 1994a,b). Therefore, a direct classic neurotrophic effect on the GABAergic projection neurons seems unlikely because it would require either effective signaling at very low levels of these receptors (below the detection limits of present available techniques) or, alternatively, one may have to postulate the exis- tence of an unknown functional receptor for NGF in these neurons. In this context, it should be pointed out that neuroprotective effects of NGF have been observed on adult rat hippocampal neurons (Shigeno et al., 1991; Pechan et al., 1995), which could be mediated by the Trk receptor present at very low levels (Cellerino, 1996).

It seems quite possible, on the other hand, that the NGFinduced protection of striatal spiny projection neurons may occur through an indirect, neuron-mediated mechanism. Neurotrophins have been shown to induce activity-dependent, short- and longterm changes in synaptic strength (for review, see Thoenen, 1995; Lo, 1995), and in particular NGF has been shown to stimulate glutamate release in vivo (Knipper et al., 1994). In the neostriatum, such effects could render the striatal neurons less sensitive to a subsequent quinolinic acid overstimulation.

In a different context, NGF-glia interactions may provide a non-neuronal indirect neuroprotective mechanism. Microglia and the production and secretion of tissue-type plasminogen activator (tPA) have been recently demonstrated to play an essential role mediating neuronal death in the hippocampus after excitotoxic lesions (Tsirka et al., 1995). Interestingly, a few years ago NGF was recognized as a modulator of tPA and plasminogen activator inhibitor metabolism in PC12 cells (Leprince et al., 1991); NGF thus appeared to activate the release of the inhibitor molecule, which would extracellularly bind to the tPA, abolishing its action. This mechanism may provide a rather simple explanation of the generalized neuroprotective effects of NGF observed in our experimental paradigm; the reduced microglial reaction seen in the present work may be taken in support of this idea.

Another possible explanation of the generalized survival effect of NGF in the excitotoxic model used here may involve a general detoxifying effect of NGF by stimulation of free radical scavenging systems. In this respect, NGF has been shown to stimulate the expression of catalase in the rat striatum (Frim et al., 1994) and counteract the decrease in several free radical metabolic enzymes in aged rats (Nisticó et al., 1992). Moreover, NGF has been reported to enhance the antioxidant balance in cultures of PC12 cells and sympathetic neurons, protecting the cultured cells from neuronal injury by hydrogen peroxide and reactive oxygen species (Jackson et al., 1990a,b, 1994; Greenlund et al., 1995).

Regardless of the precise molecular or cellular mechanism ultimately responsible for the generalized neuroprotection exerted by NGF in the present model, there is still one aspect of this NGF action not easily explained: the apparent discrepancy between the generalized (affecting diverse types of neurons) versus cholinergic-specific effects of NGF when the neurotrophin is delivered either by ex vivo gene transfer before the lesion (Schumacher et al., 1991; Frim et al., 1993a,b; Emerich et al., 1994; present study), compared with direct infusion or injection of NGF into the brain, or by systemic delivery, simultaneous to the lesion (Davies and Beardsall, 1992; Kordower et al., 1994; Venero et al., 1994a). It seems possible that the host striatum may require a preexposure to the neurotrophin to develop the protective cellular mechanisms needed to compensate for the toxicity of the lesion, as observed in cultures of hippocampal neurons, PC-12 cells, and cerebellar neurons (for discussion, see Tatter et al., 1995, and references cited therein). This would in turn speak in favor of the need of chronic and continuous supply of neurotrophins to generate a neuroprotective environment in the damaged striatum. Gene transfer procedures are well suited to provide such delivery systems. Indeed, the transduced stem cells used here have been 


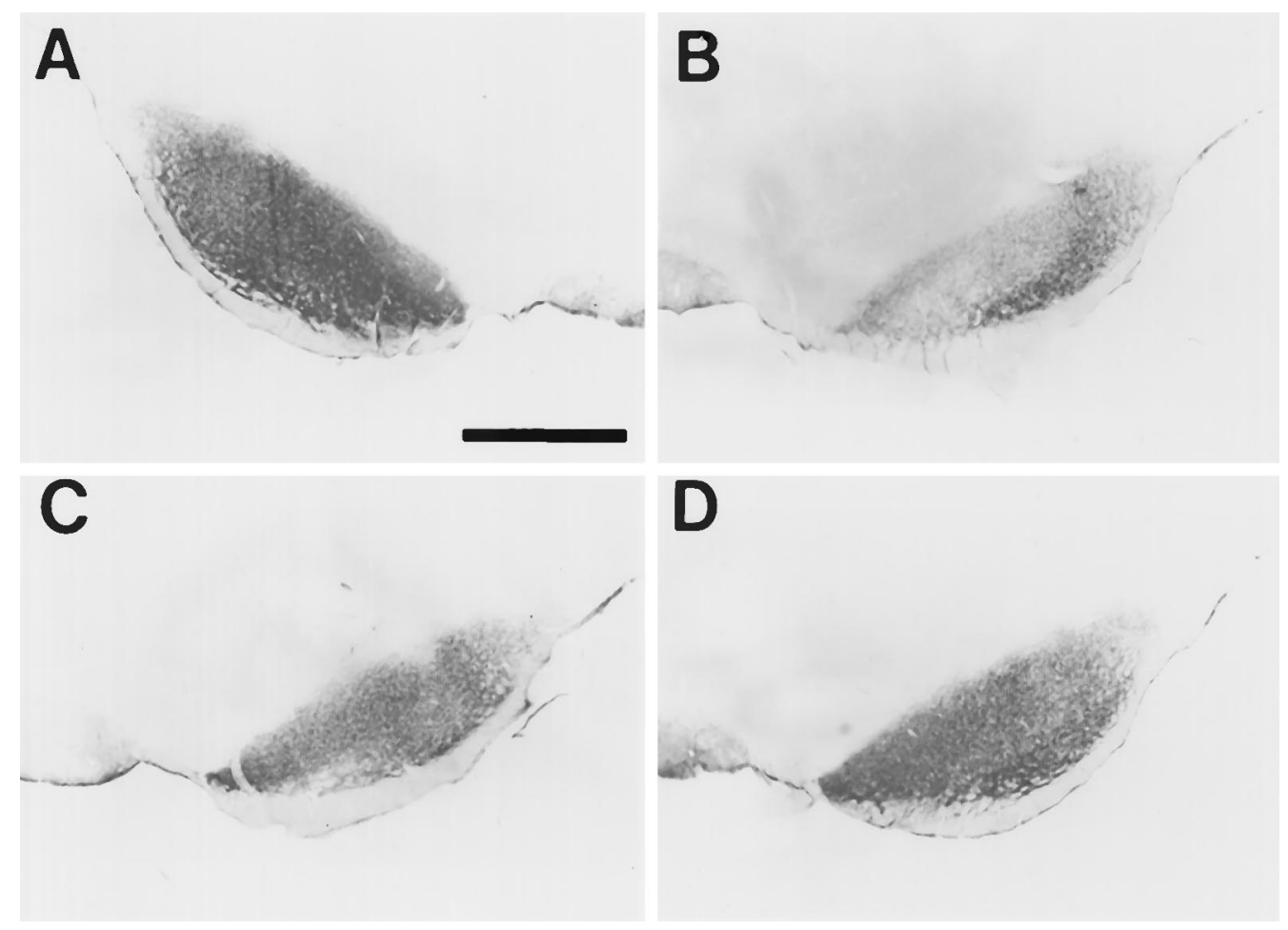

Figure 7. Preservation of the striatal projection neuron innervation (DARPP-32-immunoreactive fibers) of the pars reticulata of the substantia nigra by neurotrophin-producing cell grafts. The microphotographs show DARPP-32 immunostaining of the ventral mesencephalon region from representative animals from the sham- and control-grafted group $(B)$ compared with the BDNF- $(C)$ or NGF- $(D)$ grafted animals. Note that fiber staining is mostly preserved in the neurotrophin (particularly NGF)-treated animals, but greatly diminished in sham- or control-grafted animals group. The appearance of the intact (no surgery-no lesion) side is included $(A)$ for histological comparison. Results of the morphometric analyses (optical density and area of the immunostained regions) are given in Table 1 . Scale bar, $1 \mathrm{~mm}$.

shown to provide long-term in vivo NGF delivery, as detected by reverse transcriptase-polymerase chain reaction and bioactivity (Martínez-Serrano et al., 1995b) or by direct measurement of NGF protein content in the brain of transplanted animals up to 2.5 months after surgery (Martínez-Serrano et al., 1996b).

\section{Effects of BDNF-secreting grafts}

In an experimental paradigm similar to the one used here, fibroblasts genetically modified to express a minigene coding for BDNF were found not to have any significant neuroprotective effect on striatal GABAergic neurons (Frim et al., 1993a); accordingly, in our study, even though the BDNF cell-grafted group showed a general trend to increased neural rescue, the effects were not clear-cut, and in several parameters nonsignificant. Interestingly, even though the BDNF-secreting cells did not significantly affect quantitative parameters of neuronal survival (see Figs. 3, 6), there was a partial preservation of the innervation of the globus pallidus by striatal fibers (as assessed by densitometry of DARPP-32-immunostained sections, Table 1).

\section{Conclusion}

Gene transfer procedures based on the use of immortalized neural stem cells or progenitors have emerged as an interesting new research tool to address questions related to mechanisms of neuroprotection in the CNS, and they may provide a basis for the development of cellular vectors for gene transfer of clinically relevant transgenes to the CNS. By providing a long-term source of transgenic proteins to the brain, evenly distributed at the target region and (because of the ability of these cells to differentiate mainly into a glial phenotype in adult recipients) in close contact with receptive neuronal elements, prominent trophic effects have been obtained in several neurodegeneration models. Efficient long-term neurotrophin delivery by gene transfer using engineered neural stem cells should be helpful in elucidating the mechanisms underlying the neurotrophin-induced neuroprotective effects in the rat HD model, and should clarify whether they represent a direct (receptor-mediated) trophic action on the GABAergic projection neurons or take place through an indirect detoxifying mechanism acting via the resident glial cell population. Moreover, because prolonged in vivo long-term transgene expression has been demonstrated in intracerebral transplants of transduced neural stem cells, these cell lines should be useful in experiments designed to test the effects of sustained NGF delivery in long-term studies of progressive striatal degeneration. In the absence of any effective therapy for HD aiming to prevent or slow the rate of degeneration of striatal neuronal elements, neurotrophin gene transfer may offer a feasible approach for the preventive treatment of neurodegeneration in the striatum. Indeed, by protecting the endogenous structures of the brain in the striatal complex, it may indeed be possible to avoid degeneration in other regions of the brain, such as globus pallidus, substantia nigra, or neocortex, thought to appear as secondary events attributable to transneuronal degeneration in HD.

Future studies, focused on functional effects on complex motor and cognitive behaviors in the rat HD model, are needed to evaluate the usefulness and long-term efficacy of trophic-factor gene transfer procedures to counteract the long-lasting functional 

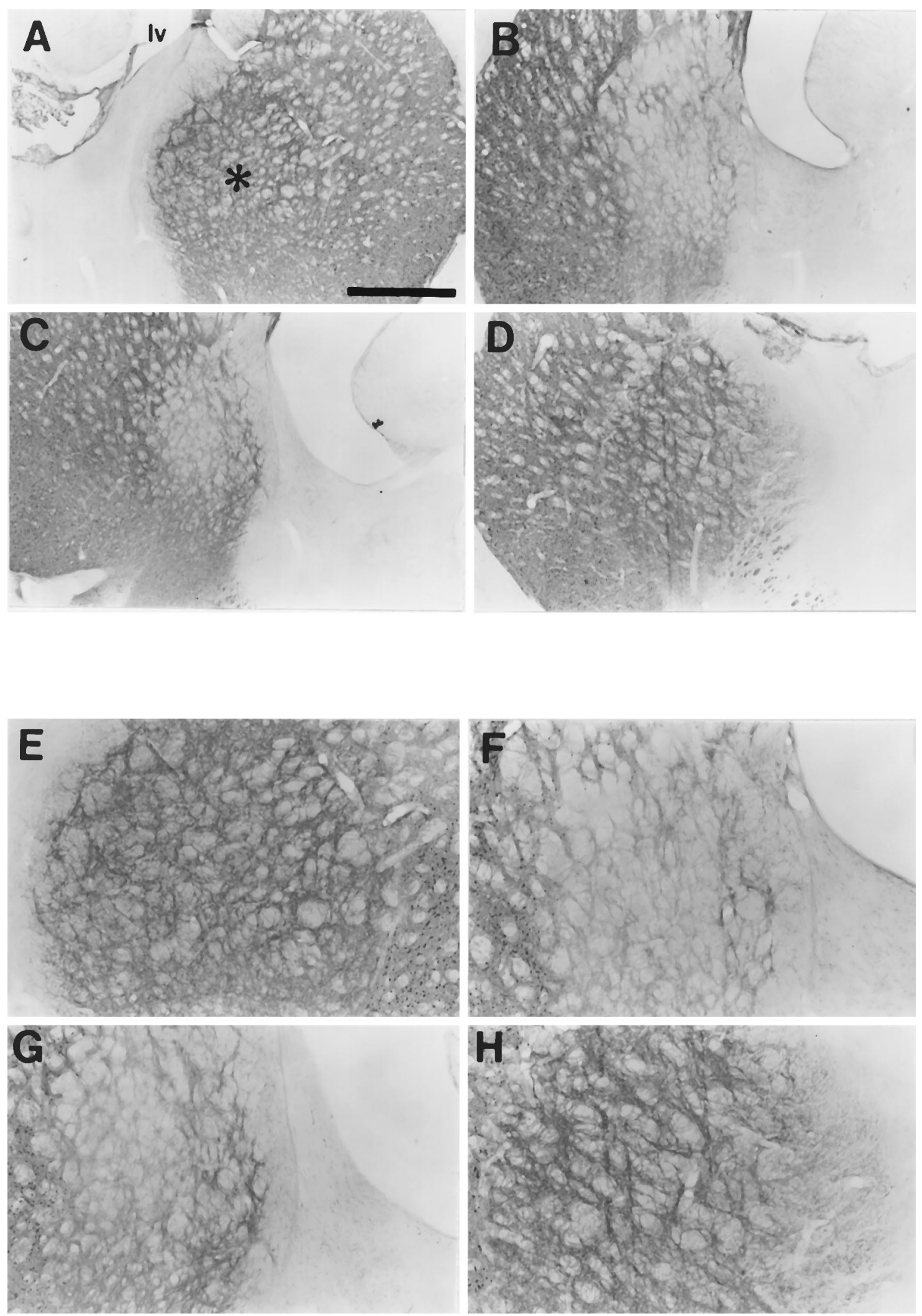

Figure 8. Globus pallidus innervation by DARPP-32-immunoreactive striatal fibers is preserved by neurotrophin-producing transplants. The top and bottom panels, respectively, illustrate low- and high-power views of the globus pallidus region in the sham- and control-grafted group ( $B, F)$ compared with the BDNF- $(C, G)$ or NGF- $(D, H)$ grafted animals. As shown for $\mathrm{SNr}$ in Figure 8, innervation appears mostly preserved by the transplantation of the BDNF- or NGF-producing cells (compared with the intact side, shown in $A, E$ ). Quantitative data are provided in Table 1. Scale bar (shown in $A$ ), $1 \mathrm{~mm}$ in $A-D, 500 \mu \mathrm{m}$ in $E-H$. 

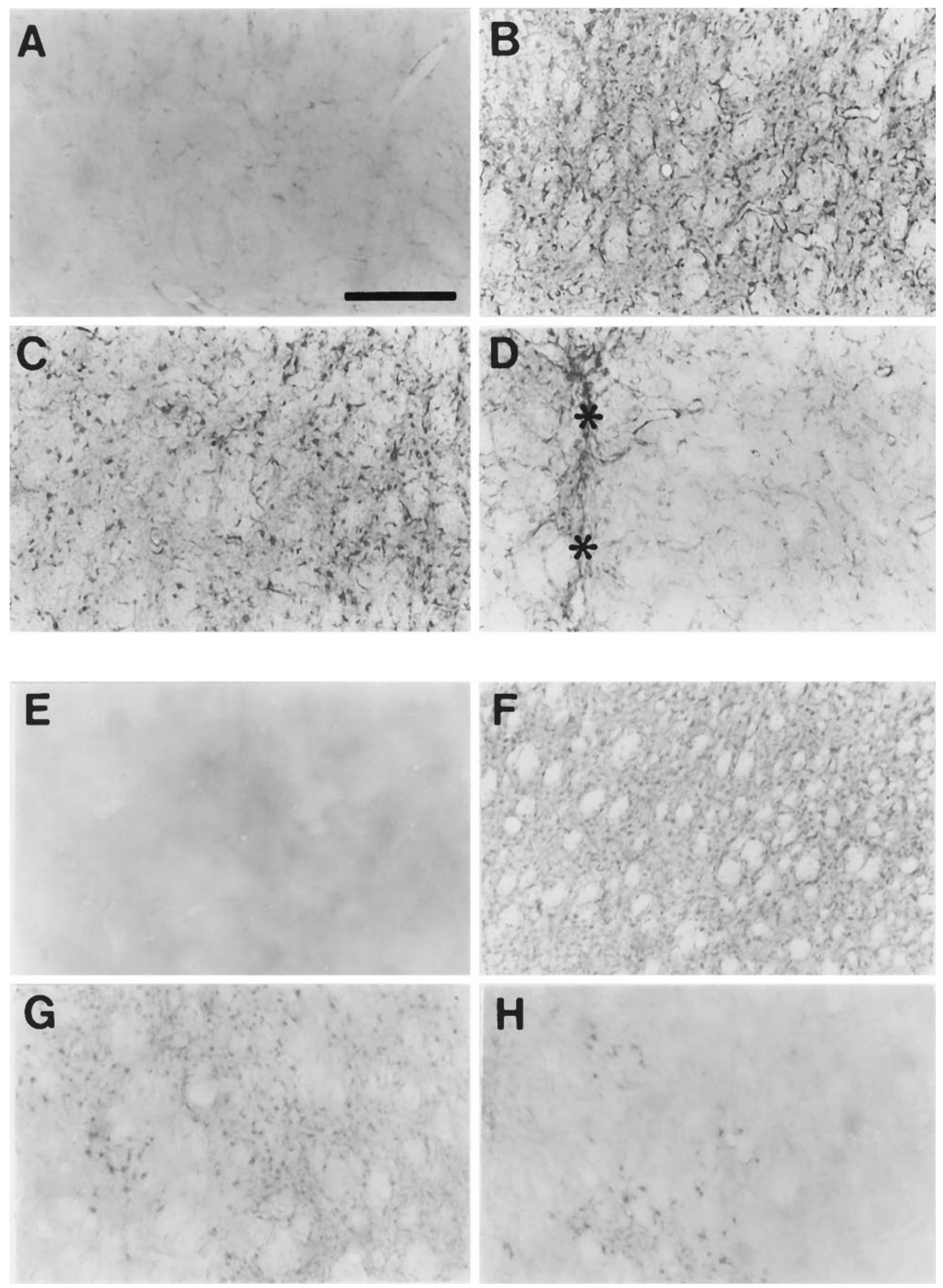

Figure 9. Glial reaction to the excitotoxic lesion is diminished in the neurotrophin-treated striata. The photomicrographs show GFAP (astrocytic marker, top panels, $A-D$ ) or OX-42 (microglial and macrophage marker, bottom panels, $E-H$ ) immunostaining of sections at the level where the quinolinic acid lesion peaks in representative animals from each of the experimental groups: sham- and control- $(B, F)$, BDNF- $(C, G)$, and NGF- $(D, H)$ grafted animals; the intact side is shown for reference in $A$ and $E$. Note the marked reduction in reactive glial cells present in the NGF-treated group. The asterisks in $D$ (NGF-grafted) denote one of the injection tracks and the associated reactive astrogliosis, in contrast to the low upregulation of GFAP in the surrounding tissue. Scale bar, $250 \mu \mathrm{m}$. 
deficits accompanying neurodegenerative processes in the lesioned striatum and also promote functional recovery induced by intrastriatal striatal grafts in the rat HD model.

\section{REFERENCES}

Albin RL, Young AB, Penney JB (1989) The functional anatomy of basal ganglia disorders. Trends Neurosci 12:366-375.

Anton R, Kordower JH, Maidment NT, Manaster JS, Kane DJ, Rabizadeh S, Scueller SB, Yang J, Rabizadeh S, Edwards RH, Bredesen DE (1994) Neural-targeted gene therapy for rodent and primate hemiparkinsonism. Exp Neurol 127:207-218.

Björklund A, Campbell K, Sirinathsinghji DJ, Fricker RA, Dunnett SB (1994) Functional capacity of striatal transplants in the rat Huntington model. In: Functional neural transplantation (Dunnett SB, Björklund A, eds), pp 157-195. New York: Raven.

Cellerino A (1996) Expression of messenger RNA coding for the nerve growth factor receptor TrkA in the hippocampus of the adult rat. Neuroscience 70:613-616.

Chang HT, Kita H (1992) Interneurons in the rat striatum: relationships between parvalbumin neurons and cholinergic neurons. Brain Res 574:307-311.

Davies SW, Beardsall K (1992) Nerve growth factor selectively prevents excitotoxin induced degeneration of striatal cholinergic neurones. Neurosci Lett 140:161-164.

DiChiara G, Morelli M, Consolo S (1994) Modulatory functions of neurotransmitters in the striatum: $\mathrm{ACh} /$ dopamine/NMDA interactions. Trends Neurosci 17:228-233.

DiFiglia M (1990) Excitotoxic injury of the neostriatum: a model for Huntington's disease. Trends Neurosci 13:286-289.

Duan W-M, Widner H, Björklund A, Brundin P (1993) Sequential intrastriatal grafting of allogeneic embryonic dopamine-rich neuronal tissue in adult rats: will the second graft be rejected? Neuroscience 57:261-274.

Dunnett SB, Svendsen CN (1993) Huntington's disease: animal models and transplantation repair. Curr Opin Neurobiol 3:790-796.

Dusart I, Marty S, Peschanski M (1991) Glial changes following an excitotoxic lesion in the CNS. II. Astrocytes. Neuroscience 45:541-549.

Emerich DF, Hammang JP, Baetge EE, Winn SR (1994) Implantation of polymer-encapsulated human nerve growth factor-secreting fibroblasts attenuates the behavioral and neuropathological consequences of quinolinic acid injections into rodent striatum. Exp Neurol 130:141-150.

Fisher LJ, Ray J (1994) In vivo and ex vivo gene transfer to the brain. Curr Opin Neurobiol 4:735-741.

Frim DM, Uhler TA, Short MP, Ezzedine ZD, Klagsbrun M, Beakefield XO, Isacson O (1993a) Effects of biologically delivered NGF, BDNF and bFGF on striatal excitotoxic lesions. NeuroReport 4:367-370.

Frim DM, Yee WM, Isacson O (1993b) NGF reduces striatal excitotoxic neuronal loss without affecting concurrent neuronal stress. NeuroReport 4:655-658

Frim DM, Wüllner U, Beal MF, Isacson O (1994) Implanted NGFproducing fibroblasts induce catalase and modify ATP levels but do not affect glutamate receptor binding or NMDA receptor expression in the rat striatum. Exp Neurol 128:172-180.

Gage FH, Batchelor P, Chen KS, Chin D, Higgins GA, Koh S, Deputy S, Rosenberg MB, Fischer W, Björklund A (1989) NGF receptor reexpression and NGF-mediated cholinergic neuronal hypertrophy in the damaged adult neostriatum. Neuron 2:1177-1184.

Gage FH, Ray J, Fisher LJ (1995) Isolation, characterization, and use of stem cells from the CNS. Annu Rev Neurosci 18:159-192.

Greenlund LJ, Deckwerth TL, Johnson Jr EM (1995) Superoxide dismutase delays neuronal apoptosis: a role for reactive oxygen species in programmed neuronal death. Neuron 4:303-315.

Gundersen HJG, Bendtsen TF, Korbo L, Marcussen N, Moller A, Nielsen K, Nyengaard JR, Pakkenberg B, Sorensen FB, Vesterby A, West MJ (1988) Some new, simple and efficient stereological methods and their use in pathological research and diagnosis. Acta Pathol Microbiol Immunol Scand 96:379-394.

Hagg T, Hagg F, Vahlsing Manthorpe M, Varon S (1989) Nerve growth factor effects on cholinergic neurons of neostriatum and nucleus accumbens in the adult rat. Neuroscience 30:95-103.

Higgins GA, Koh S, Chen K, Gage FH (1989) NGF induction of NGF receptor gene expression and cholinergic neuronal hypertrophy within the basal forebrain of the adult rat. Neuron 3:247-256.
Holtzman DM, Li Y, Parada LF, Kinsman S, Chen CK, Valletta JS, Zhou J, Long JB, Mobley WC (1992) p140 ${ }^{\text {trk }}$ mRNA marks NGF-responsive forebrain neurons: evidence that trk gene expression is induced by NGF. Neuron 9:465-478.

Isacson O, Fischer W, Wictorin K, Dawbarn D, Björklund A (1987) Astroglial response in the excitotoxically lesioned neostriatum and its projection areas in the rat. Neuroscience 3:1043-1056.

Jackson JR, Apffel L, Werrbach-Perez K, Perez-Polo JR (1990a) Role of nerve growth factor in oxidant-antioxidant balance and neuronal injury. I. Stimulation of hydrogen peroxide resistance. J Neurosci Res 25:360-368.

Jackson JR, Werrbach-Perez K, Perez-Polo JR (1990b) Role of nerve growth factor in oxidant-antioxidant balance and neuronal injury. II. A conditioning lesion paradigm. J Neurosci Res 25:369-374.

Jackson JO, Werrbach-Perez K, Pan Z, Sampath D, Perez-Polo JR (1994) Neurotrophin regulation of energy homeostasis in the central nervous system. Dev Neurosci 16:285-290.

Kawaguchi Y, Wilson Ch J, Augood SJ, Emson PC (1995) Striatal interneurons: chemical, physiological and morphological characterization. Trends Neurosci 18:527-535.

Knipper M, Leung LS, Zhao D, Rylett RJ (1994) Short-term modulation of glutamatergic synapses in adult rat hippocampus. NeuroReport 5:2433-2436.

Kordower JH, Charles V, Bayer R, Bartus RT, Putney S, Walus LR, Friden PM (1994) Intravenous administration of a transferrin receptor antibody-nerve growth factor conjugate prevents the degeneration of cholinergic striatal neurons in a model of Huntington disease. Proc Natl Acad Sci USA 91:9077-9080.

Lacorazza HD, Flax JD, Snyder EY, Jendoubi M (1996) Expression of human $\beta$-hexosaminidase $\alpha$-subunit gene (the gene defect of Tay-Sachs disease) in mouse brains upon engraftment of transduced progenitor cell. Nature Medicine 2:424-429.

Leprince P, Rogister B, Delrée P, Rigo JM, André B, Moonen G (1991) Modulation of proteolytic activity during neuritogenesis in the $\mathrm{PC} 12$ nerve cell: differential control of plasminogen activator and plasminogen activator inhibitor activities by nerve growth factor and dibutyrylcyclic AMP. J Neurochem 57:665-674.

Lo DC (1995) Neurotrophic factors and synaptic plasticity. Neuron 15:979-981.

Martínez-Serrano A, Björklund A (1996) Gene transfer to the mammalian brain using neural stem cells. Focus on trophic factors, neuro-regeneration and cholinergic neuron systems. Clin Neurosci, in press.

Martínez-Serrano A, Lundberg C, Horellou P, Fischer W, Bentlage C, Campbell K, McKay RDG, Mallet J, Björklund A (1995a) CNSderived neural progenitor cells for gene transfer of nerve growth factor to the adult rat brain: complete rescue of axotomized cholinergic neurons after transplantation into the septum. J Neurosci 15:5668-5680.

Martínez-Serrano A, Fischer W, Björklund A (1995b) Reversal of agedependent cognitive impairments and cholinergic neuron atrophy by NGF-secreting neural progenitors grafted to the basal forebrain. Neuron 15:1-20.

Martínez-Serrano A, Hantzopoulos P, Björklund A (1996a) Ex-vivo gene transfer of brain-derived neurotrophic factor to the intact rat forebrain: neurotrophic effects on cholinergic neurons. Eur J Neurosci $8: 727-735$.

Martínez-Serrano A, Fischer W, Söderström S, Ebendal T, Björklund A (1996b) Long-term functional recovery from age-induced spatial memory impairments by nerve growth factor (NGF) gene transfer to the rat basal forebrain. Proc Natl Acad Sci USA 93:6355-6360.

Marty S, Dusart I, Peschanski M (1991) Glial changes following an excitotoxic lesion in the CNS: I. Microglia/macrophages. Neuroscience 45:529-539.

Merlio JP, Ernfors P, Jaber M, Persson H (1992) Molecular cloning of rat trkC and distribution of cells expressing messenger RNAs for members of the trk family in the rat central nervous system. Neuroscience 51:513-532.

Nisticó G, Ciriolo MR, Fiskin K, Iannone M, Martino A, Torilio G (1992) NGF restores decrease in catalase activity and increases superoxide dismutase and glutathione peroxidase activity in the brain of aged rats. Free Radic Biol Med 12:177-181.

Ouimet CC, Miller PE, Hemmings Jr HC, Walaas SI, Greengard P (1984) DARPP-32, a dopamine- and adenosine $3^{\prime}: 5^{\prime}$-monophosphate- 
regulated phosphoprotein enriched in dopamine-innervated brain regions. III. Immunocytochemical localization. J Neurosci 4:111-124.

Parent A, Hazrati LN (1995) Functional anatomy of the basal ganglia. I. The cortico-basal ganglia-thalamo-cortical loop. Brain Res Rev 20:91-127.

Paxinos G, Watson C (1986) The rat brain in stereotaxic coordinates. New York: Academic.

Pechan PA, Yoshida T, Panahian N, Moskowitz MA, Breakefield XO (1995) Genetically modified fibroblasts producing NGF protect hippocampal neurons against ischemia in the rat. NeuroReport 6:669-672.

Peschanski M, Cesaro P, Hantraye P (1995) Rationale for intrastriatal grafting of striatal neuroblasts in patients with Huntington's disease. Neuroscience 68:273-285.

Renfranz PJ, Cunningham MG, McKay RDG (1991) Region-specific differentiation of the hippocampal stem cell line HiB5 upon implantation into the developing mammalian brain. Cell 66:713-729.

Roberts RC, Ahn A, Swartz KJ, Beal MF, DiFiglia M (1993) Intrastriatal injections of quinolinic acid or kainic acid: differential patterns of cell survival and the effects of data analysis on outcome. Exp Neurol 124:274-282.

Schumacher JM, Short MP, Hyman BT, Breakefield XO, Isacson O (1991) Intracerebral implantation of nerve growth factor-producing fibroblasts protects striatum against neurotoxic levels of excitatory amino acids. Neuroscience 45:561-570.

Shigeno T, Mima T, Takakura K, Graham DI, Kato G, Hashimoto Y, Furukawa S (1991) Amelioration of delayed neuronal death in the hippocampus by nerve growth factor. J Neurosci 11:2914-2919.
Snyder EY (1994) Grafting immortalized neurons to the CNS. Curr Opin Neurobiol 4:742-751.

Snyder EY, Taylor RM, Wolfe JH (1995) Neural progenitor cell engraftment corrects lysosomal storage throughout the MPS VII mouse brain. Nature 374:367-370.

Tatter SB, Galpern WR, Isacson O (1995) Neurotrophic factor protection against excitotoxic neuronal death. The Neuroscientist 1:286-297.

Thoenen H (1995) Neurotrophins and neuronal plasticity. Science 270:593-598

Tsirka SE, Gualandris A, Amaral DG, Strickland S (1995) Excitotoxininduced neuronal degeneration and seizure are mediated by tissue plasminogen activator. Nature 377:340-344.

Venero JL, Beck KD, Hefti F (1994a) Intrastriatal infusion of nerve growth factor after quinolinic acid prevents reduction of cellular expression of choline acetyltransferase messenger RNA and trkA messenger RNA, but not glutamate decarboxylase messenger RNA. Neuroscience 61:257-268.

Venero JL, Knüsel B, Beck KD, Hefti F (1994b) Expression of neurotrophin and trk receptor genes in adult rats with fimbria transections: effect on intraventricular nerve growth factor and brain-derived neurotrophic factor administration. Neuroscience 59:797-815.

Wictorin K, Ouimet CC, Björklund A (1989) Intrinsic organization and connectivity of intrastriatal transplants in rats as revealed by DARPP-32 immunohistochemistry: specificity of connections with the lesioned host brain. Eur J Neurosci 1:690-701.

Young AB (1995) Huntington's disease: lessons from and for molecular neuroscience. The Neuroscientist 1:51-58. 